\title{
Temperature Sensitivity of Sporulation in Bacillus cereus
}

\author{
By GABRIELA ISSAHARY, I. HERTMAN AND Z. EVENCHIK \\ Department of Microbiology, Israel Institute for Biological Research, \\ Ness-Ziona, Israel
}

(Received 6 August 1974)

\section{INTRODUCTION}

Conditional heat-sensitive asporogenic mutants are useful for elucidating the functions involved in spore formation. Such mutants isolated from Bacillus subtilis exhibited heat sensitivity at either early (Leighton et al. 1972) or median stages (Leighton, 1973) of sporulation. Mutants of Bacillus cereus which sporulate at $28^{\circ} \mathrm{C}$ but not at $37^{\circ} \mathrm{C}$ have been described by Lundgren \& Cooney (1962) and by Stelma \& Sadoff (1973). We have observed that wildtype strains of $B$. cereus which grow and sporulate at $37^{\circ} \mathrm{C}$ grew at $44{ }^{\circ} \mathrm{C}$ but failed to sporulate at that temperature. Comparative studies of morphological and physiological changes associated with sporulation were carried out at the permissive and at the restrictive temperature in a directed-sporulation system. Shift-up and shift-down experiments with $B$. cereus 569 in directed-sporulation culture show that some early functions involved in sporulation display heat sensitivity.

\section{METHODS}

Organisms. These were: Bacillus cereus NRRL569; B. cereus T; B. cereus ATCC6464; B. cereus ATCC7004; B. subtilis I68SB25 (try ${ }^{-}$, his ${ }^{-}$).

Media. Difco nutrient broth and PA medium (Thorne, 1968) were used for routine growth and sporulation. Directed-sporulation was carried out in PA medium modified to contain $(\mathrm{g} / \mathrm{l})$ : Difco nutrient broth, $\mathrm{I} \cdot 5 ; \mathrm{NaCl}, 5 ; \mathrm{MgSO}_{4} \cdot 7 \mathrm{H}_{2} \mathrm{O}, 0 \cdot 2 ; \mathrm{MnSO}_{4} \cdot \mathrm{H}_{2} \mathrm{O}, 0 \cdot 05 ; \mathrm{CaCl}_{2} \cdot 2 \mathrm{H}_{2} \mathrm{O}$, 0.3 .

Directed-sporulation conditions. A vegetative inoculum was prepared from cultures grown in PA medium at $37^{\circ} \mathrm{C}$ to a concentration of about $\mathrm{I} \times 10^{8}$ colony-forming units $/ \mathrm{ml}$, equivalent to an extinction of 0.40 at $540 \mathrm{~nm}$ (Coleman Junior spectrophotometer). Bacteria were harvested by centrifuging, kept at $4{ }^{\circ} \mathrm{C}$ overnight and resuspended in sporulation medium (extinction 0.62 at $540 \mathrm{~nm}$ ). The suspensions were shaken at $37{ }^{\circ} \mathrm{C}$ in flasks filled to I/Ioth of their volume.

Spore count. Spores were counted after heat treatment at $80^{\circ} \mathrm{C}$ for $30 \mathrm{~min}$.

Biochemical tests. RNA synthesis in directed-sporulation culture was assayed by measuring the incorporation of $\left[2{ }^{14} \mathrm{C}\right]$ uracil during $\mathrm{I}$ and $30 \mathrm{~min}$ pulses. Radioactivity was determined using a Packard 'Tricarb' liquid scintillation spectrometer. Aconitase activity was determined in extracts by the procedure of Racker (1950) using trisodium citrate as substrate. Protein was measured by the method of Lowry, Rosebrough, Farr \& Randall (195I). Proteolytic activity of the crude supernatant solutions was determined according to the method of Millet (I970) with minor modifications. The substrate employed was $0.5 \%$ Azoalbumin $\left(E_{440}^{1 \%}=35\right.$; Sigma $)$ in $0 \cdot 2$ M-tris- $\mathrm{HCl}$ buffer $\mathrm{pH} 7 \cdot 2$. 

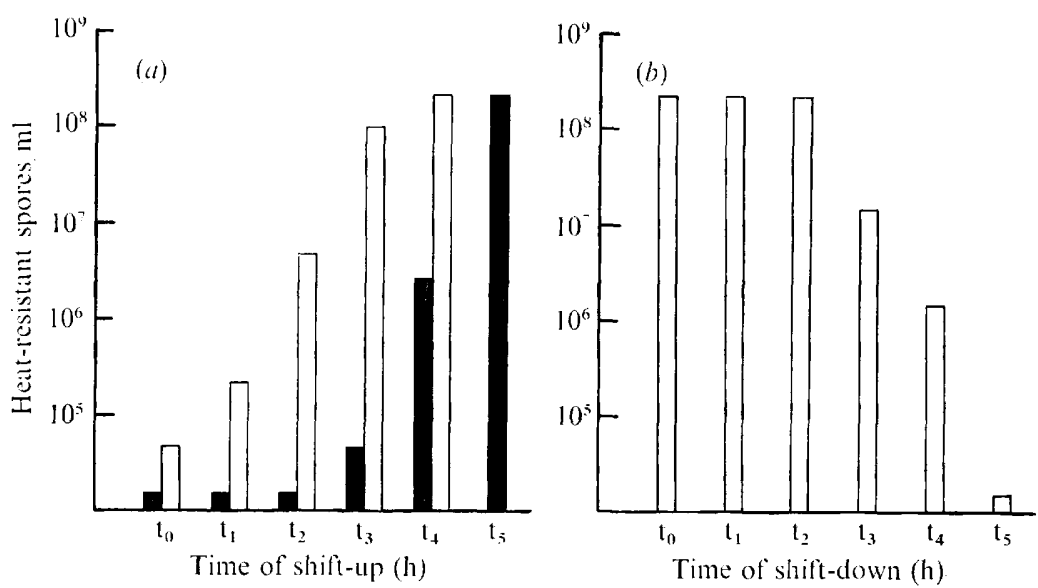

Fig. 1. Sporulation of B. cereus 569 cultures shifted during directed-sporulation. (a) Shift-up from 37 to $44{ }^{\circ} \mathrm{C}$; each sample was examined for spore concentration at the time of transfer (solid columns) and after further incubation at $44^{\circ} \mathrm{C}$ up to $5 \mathrm{~h}$ (white columns). (b) Shift-down from 44 to $37^{\circ} \mathrm{C}$; cultures were incubated at $44^{\circ} \mathrm{C}$, shifted down to $37^{\circ} \mathrm{C}$ at $\mathrm{I} \mathrm{h}$ intervals for an additional $5 \mathrm{~h}$ of incubation and then examined for spore concentration.

\section{RESULTS AND DISCUSSION}

The yields of sporulation in Bacillus cereus 569 grown at 37 and $44{ }^{\circ} \mathrm{C}$ were found to be $2 \times 10^{8}$ spores $/ \mathrm{ml}$ and $5 \times 10^{5}$ spores $/ \mathrm{ml}$, respectively. Sporulation of other strains, $B$. cereus $\mathrm{T}, B$. cereus 6464 and $B$. cereus 7004 , exhibited a similar heat sensitivity at the higher temperature. B. subtilis I68-SB, however, sporulated equally well both at 37 and $44{ }^{\circ} \mathrm{C}$. The heat sensitivity of $B$. cereus was restricted to the sporulation phase since vegetative growth at $44{ }^{\circ} \mathrm{C}$ was hardly impaired. Shift-up experiments in the stationary phase showed that sporulation at $44^{\circ} \mathrm{C}$ was inhibited independent of the vegetative growth temperature.

A directed-sporulation system was introduced to investigate the heat sensitivity of various stages of the sporulation process. Samples from cultures termed $t_{0}, t_{1} \ldots t_{5}$ were withdrawn at I h intervals and scored for heat-resistant spores. At $37^{\circ} \mathrm{C}$, forespores viewed under the phase microscope were prominent at $t_{3}$, followed by refractile spores at $t_{4}$. A high yield of heat-resistant spores was obtained at $t_{5}$. Incubation of directed-sporulation cultures at $44{ }^{\circ} \mathrm{C}$, however, resulted in a low yield of spores; no morphological differentiation could be detected on microscopic examination. No change in the extinction of cultures was recorded at either temperature during period $t_{0}$ to $t_{4}$.

Shift-up experiments were carried out in this system. Samples transferred from $37^{\circ} \mathrm{C}$ at I $\mathrm{h}$ intervals were incubated at $44{ }^{\circ} \mathrm{C}$ for up to $5 \mathrm{~h}$ and examined for spore yield. The sporulation temperature sensitivity was limited to stages $t_{0}$ to $t_{2}$, as shown by the low yield of spores in cultures shifted up at these stages (Fig. I $a$ ). It appears that the heat-induced asporogenicity of Bacillus cereus is due to the inhibition of early events of sporulation and that the sporulating organisms become heat sensitive $2 \mathrm{~h}$ before their maturation into heatresistant spores.

To determine whether sporulation capacity could be restored by transfer to the permissive temperature, directed-sporulation cultures at $44{ }^{\circ} \mathrm{C}$ were shifted down at $\mathrm{I} \mathrm{h}$ intervals to $37^{\circ} \mathrm{C}$ for an additional incubation period of $5 \mathrm{~h}$. The heat-induced asporogenicity (Fig. I $b$ ) could be reversed only if shift-down took place during the first $2 \mathrm{~h}$ at $44{ }^{\circ} \mathrm{C}\left(\mathrm{t}_{0}\right.$ to $\left.\mathrm{t}_{2}\right)$. The maximum spore yield in these cultures was $2 \times 10^{8} / \mathrm{ml}$. In cultures shifted down at $t_{3}, t_{4}$ and 
$t_{5}$, spore yields were reduced to $2 \times 10^{7} / \mathrm{ml}, 1 \cdot 5 \times 10^{6} / \mathrm{ml}$ and $2 \times 10^{5} / \mathrm{ml}$, respectively. Failure to sporulate after shift-down to $37^{\circ} \mathrm{C}$ at $t_{3}$ to $t_{5}$ was not due to increased mortality at $44{ }^{\circ} \mathrm{C}$. Hardly any change in the number of colony-forming units could be detected during the phase $t_{0}$ to $t_{2}$ at $44{ }^{\circ} \mathrm{C}$. At $t_{5}$, about $20 \%$ of the initial colony-forming units could still be recovered. A temperature-sensitive irreversible event seems to occur early in sporulation, which does not preclude bacteria from re-entering their vegetative growth cycle at $37^{\circ} \mathrm{C}$ since, when plated at $37^{\circ} \mathrm{C}$, they grew into spore-containing colonies.

Early stages of sporulation involve RNA precursor incorporation (Ramaley \& Burden, I970), a functional tricarboxylic acid cycle (Ramaley \& Burden, 1970; Szulmajster, 1973), and derepression of the synthesis of proteolytic enzymes (Mandelstam \& Waites, I968; Szulmajster, 1973). At $37^{\circ} \mathrm{C}$, RNA precursor incorporation, enhanced activity of aconitase and a rise in the $\mathrm{pH}$ of the medium (from 5.9 to $7 \cdot \mathrm{I}$ ) were characteristic for stages $\mathrm{t}_{\mathbf{0}}$ and $\mathrm{t}_{1}$; the appearance of a exoproteolytic activity followed at $\mathrm{t}_{2}$. At $44{ }^{\circ} \mathrm{C},\left[2-{ }^{14} \mathrm{C}\right]$ uracil incorporation into both total RNA and the rapidly labelled fraction of RNA was smaller than that obtained at $37^{\circ} \mathrm{C}$. This finding is similar to that reported for a heat sensitive asporogenic mutant of Bacillus subtilis blocked at early stages of sporulation (Szulmajster, Bonamy \& Laporte, 1970). An initial rise in aconitase specific activity at $t_{1}$ was followed by a decline in the activity at $t_{2}$, at both permissive and restrictive temperature. In contrast, an overproduction of this enzyme was reported for a heat-sensitive asporogenic mutant of $B$. subtilis under restrictive conditions (Leighton et al. 1972). It appears, therefore, that late vegetative functions are not altered in our system at $44^{\circ} \mathrm{C}$. Exoproteolytic activity characteristic of stages $t_{2}$ and $t_{3}$ at $37^{\circ} \mathrm{C}$ was negligible at $44^{\circ} \mathrm{C}$. A similar observation has been reported for a conditional asporogenic mutant of $B$. subtilis (Leighton et al. 1972). The absence of exoproteolytic activity in $B$. cereus 569 at $44^{\circ} \mathrm{C}$ was not due to inactivation of the enzyme at that temperature, since proteolytic activity in control supernatant solutions was not affected by the pre-incubation at $44{ }^{\circ} \mathrm{C}$ for $\mathrm{I} \mathrm{h}$.

Induction of sporulation is assumed to involve changes in the template specificity of RNA polymerase (Losick \& Sonnenschein, 1969; Leighton et al. 1972; Szulmajster, 1973). In $B$. subtilis susceptibility to sporulation is limited to certain stages in the DNA replication cycle (Dawes, Kay \& Mandelstam, 1971) and Szulmajster (1973) suggested that a specific location of DNA within the cell might be required for selective transcription of genes during sporulation. Our results with $B$. cereus 569 wild-type, suggest that during prolonged incubation at $44{ }^{\circ} \mathrm{C}$ the availability of the DNA template for transcription of sporulation genes might be irreversibly altered. We cannot however exclude the possibility that some vegetative functions, which are more essential for sporulation than vegetative growth, are damaged at the restrictive temperature.

We are grateful to Professor J. Mandelstam for comments on the manuscript and to $\mathrm{Mr}$ H. Weisselberg for excellent technical assistance.

\section{REFERENCES}

Dawes, I. W., Kay, D. \& Mandelstam, J. (I97I). Determinating effect of growth medium on the shape and position of daughter chromosomes and on sporulation in Bacillus subtilis. Nature, London 230, $567-569$.

Leighton, T. J. (1973). An RNA polymerase mutation causing temperature sensitive sporulation in Bacillus subtilis. Proceedings of the National Academy of Sciences of the United States of America 70, I I 70-I I 83.

Leighton, T. J., Freeze, P. K., Doi, R. H., Warren, R. A. J. \& Kelln, R. A. (1972). Initiation of sporulation. In Bacillus subtilis: requirement for serine protease activity and ribonucleic acid polymerase modification. In Spores, vol. 5, pp. 238-246. Edited by H. O. Halvorson, R. Hanson and L. L. Campbell. American Society for Microbiology. 
Losick, R. \& SONNENSCHEIN, A. J. (I969). Change in the template specificity of RNA polymerase during sporulation of Bacillus subtilis. Nature, London 224, 35-37.

Lowry, O. H., Rosebrough, N. J., Farr, A. L. \& Randall, R. J. (I95I). Protein measurement with the Folin phenol reagent. Journal of Biological Chemistry 193, 265-275.

Lundgren, D. G. \& CoONEY, J. J. (1962). Chemical analysis of asporogenic mutants of Bacillus cereus. Journal of Bacteriology 83, I287-1293.

Mandelstam, J. \& WaItes, W. M. (1968). Sporulation of Bacillus subtilis: the role of exoprotease. Biochemical Journal ro9, 793-80I.

Millet, A. (1970). Characterisation of proteinases excreted by Bacillus subtilis Marburg strain during sporulation. Journal of Applied Bacteriology 33, 207-219.

RACKER, E. (1950). Spectrophotometric measurement of the enzymatic formation of fumaric and cisaconitic acids. Biochimica and biophysica acta 4, 2 I I-214.

Ramaley, R. F. \& BURDen, L. (1970). Replacement sporulation of Bacillus subtilis I 68 in a chemically defined medium. Journal of Bacteriology ror, I-8.

Stelma, G. N. \& SAdofF, H. L. (1973). Production of bacteriophage by temperature sensitive sporulation mutant of Bacillus cereus $\mathrm{T}$. Journal of Bacteriology Ir6, IO0I-IOIO.

SzulmajsTeR, J. (1973). Initiation of bacterial sporogenesis. In Microbial Differentiation, pp. 45-83. Edited by J. M. Ashworth and J.E. Smith. 23rd Symposium of the Society for General Microbiology: Cambridge University Press.

Szulmajster, J., Bonamy, C. \& LAPORTE, J. (1970). Isolation and properties of temperature sensitive sporulation mutant of Bacillus subtilis. Journal of Bacteriology 1or, 1027-1037.

THORNE, C. B. (1968). Transducing bacteriophage for Bacillus cereus. Journal of General Virology 2, 657-662. 